\title{
ZUMA VERSUS RAMAPHOSA \\ Factors Influencing Party Choice of South Africans in the Run-up to the 2019 Elections
}

\section{Yolanda Sadie and Leila Patel}

Yolanda Sadie is an Emeritus Professor in the Department of Politics and International Relations at the University of Johannesburg

Leila Patel is the DST/NRF South African Research Chair in Welfare and Social

Development at the University of Johannesburg

\begin{abstract}
The outcome of the 2016 local government elections in which the ANC lost substantial support, fuelled early speculation on not only the outcome of the 2019 general elections, but also on the factors which were likely to determine party support. Added to this was the deteriorating political and socio-economic situation in South Africa. Against this background, two national surveys were undertaken in October/November 2017 and October/ November 2018 to establish the factors at these particular times that were likely to influence the vote choice of South Africans. From both surveys it was found that South African voters increasingly base their choice of a party on rational considerations. Trust in the president was a particularly important predictor of voter choice. In the first survey, loss of trust in the president (Zuma) resulted in a loss of faith in the ANC and in support of the party; while in the second survey, the converse was true: an increase in trust in the president (Ramaphosa) reflected an increased trust in and support for the party. Other predictors of vote choice in both surveys include a desire for socio-economic well-being and hope for a better future; the fear of losing a social grant; age; and racialised party images.
\end{abstract}

Keywords: Ramaphosa, Zuma, vote choice, surveys, trust

\section{INTRODUCTION}

Over the past 25 years, that is, since the first democratic elections in 1994, South Africa's electoral landscape has been characterised by, among other things, changes in party leadership, demographic changes, increasing poverty, 
inadequate service delivery with accompanying protests, high levels of corruption by public officials and most recently, the prevalence of 'state capture'.

Voters have increasingly indicated their willingness to switch their support across parties in both national and local elections. Post-election surveys by the Comparative National Elections Project (CNEP), for example, showed that between the 1999 and 2004 national elections 8\% of the respondents switched their voting choice, 12\% switched between 2004 and 2009, while 15\% switched parties between the 2009 and 2014 elections (Schulz-Herzenberg 2016, p. 502). Furthermore, the local government elections in 2016 resulted in a substantial decrease of support for the governing African National Congress (ANC). It gained only 57.4\% of the vote and, for the first time, went below the psychological level of $60 \%$ of support.

However, local government elections are often regarded in the literature as of a lower rank or as different from national elections. They are therefore depicted as second-order elections as opposed to first-order national elections. It is also argued that in local government elections national place-bound considerations or personal contacts tend to overwrite national party identification or ideological considerations, and that main arena conditions and considerations tend to influence and guide voters. The latter will either decide not to vote or they will turn to expressive voting - for example, voting for new or small parties to punish or reward nationally governing parties. Furthermore, turnout in local elections is generally lower ${ }^{1}$ (ECPR 2019).

Nevertheless, the outcome of the 2016 elections, as well as the deteriorating political situation in South Africa, fuelled not only early speculation on the outcome of the 2019 national elections, but also debate on the factors likely to determine party support in these elections. The shifts and complexities in the electoral landscape, which are highlighted in the first section below, resulted in a variety of explanations for the voting behaviour of South Africans over the years.

Against this background two national surveys were undertaken in October/ November 2017 (while Jacob Zuma was still president) and in October /November 2018 (when newly- elected Cyril Ramaphosa had been in office for eight months) respectively. They were to establish which factors at these particular times were likely to influence the vote choice of South Africans in 2019 and whether the reasons for supporting a particular political party had changed a year later, closer to the elections in 2019. It should be emphasised that public opinion research provides 'a photograph of society at a given time' (Harris 2012, p. 133) and does not serve as a prediction for the outcome of elections. It provides insight into and

1 Voter turnout in local government elections in South Africa has also been progressively lower than in national elections. In the 2014 general election for example, the turnout was $73.5 \%$ of the registered voters compared to $57.9 \%$ in the 2016 local government elections. 
knowledge of the perceptions and attitudes of the South African population and the mood in the country at the time when the research was undertaken.

The following section provides an overview of the electoral landscape over the years, which provides the context for the two surveys. It also has a bearing on the explanations for the voting preferences of South Africans since 1994 in the subsequent section. This is followed by the methodology of the two surveys; results on party support and loyalty; the linkage between trust, performance and democracy; and, lastly, the analysis and findings.

\section{ELECTORAL LANDSCAPE SINCE 1994}

The first three democratic elections in South Africa were characterised by overwhelming support for the ANC, reaching an all-time high of $69.7 \%$ in the 2004 elections. However, the party's support subsequently dwindled to $62 \%$ in the 2014 elections. A watershed in the party's electoral history was the local election results of 2016, where it gained only $57.4 \%$ of the vote.

Zuma's controversial rise to becoming ANC president in December 2007 (amidst numerous corruption charges against him) and the recall of President Mbeki in September 2008, fuelled the formation of the Congress of the People (COPE) in 2009 by dissidents from the ruling party who reserved their loyalty for the former president. In essence, COPE externalised the internal factionalism within the ANC (Booysen 2009, p. 85). ${ }^{2}$

A further dent to the ANC (but from the left) was the establishment of the Economic Freedom Front (EFF) in 2013 by Julius Malema, former leader of the ANC Youth League (ANCYL), who was expelled from the ANC in 2012. Its support in the 2014 elections was a modest $6 \%$, although it became the official opposition in two of the provinces. The EFF's populist rhetoric of nationalisation and economic liberation attracted the support of the youth and the workers as well as large numbers of the unemployed and informally employed. The party estimated that about $85 \%$ of its 1.1 million national votes were from voters below the age of 35 (Booysen 2015, pp. 36, 232). In the 2016 local government elections the EFF managed to gather $8.3 \%$ of the proportional representation vote, allowing it to play a strategic role in forging alliances with the Democratic Alliance (DA) in key urban areas.

2 Despite its modest performance in the 2009 elections of $7.4 \%$ at national level, COPE attained opposition status in several provinces. However, its support declined dramatically in the 2014 elections to $1 \%$ nationally in favour of the DA. The IFP's support also dwindled in 2014 to $2.4 \%$ nationally, while the party also lost what little status it had in its stronghold of KwaZulu-Natal when the DA became the official opposition in the province. 
The DA, the official opposition since 2004, showed sustained growth. It had increased its support of $12.4 \%$ in 2004 to $22.2 \%$ in 2014. In the local government elections of 2016, its support increased to $24.6 \%$, and it also took control of the three metropolitan areas lost by the ANC.

Besides the changing party landscape, there have also been demographic changes in the electorate. Since 1994 the population has become younger and more urbanised, with $64.8 \%$ of the population living in urban areas in 2015 (as against $56.9 \%$ in 2000) and an increase in the population in the 15-34 age group from 36\% in 1996 to 44\% in 2011 (Southall 2014, p.5; South Africa Survey 2017, p. 31). By 2016 eligible voters in the age group 18-39 totalled 60\% of the country's voting population, which has also resulted in changes in the electorate (South Africa Survey 2017, p. 910). This cohort was born in the mid-1980s and later, and is likely to be less influenced by the ANC's liberation credentials in its choice of party support. The urban/rural split is important, since ANC dominance is most marked in rural areas, while political discourse is largely shaped by urban concerns (Southall 2014, p. 7). The 2016 local government election results bear testimony to this divide and particularly to support for the ANC (Maserumule \& Ndletyana 2016, p. 447).

Under the presidencies of Mandela and Mbeki there was widespread optimism for South Africa's democratic future, which was accompanied by the ANC government's substantial socio-economic achievements up to 2008. In contrast, the Zuma period, particularly the second term of his office (2014-2017), was characterised by factionalism within the ANC associated with Zuma: endemic corruption, poor economic performance, deteriorating socio-economic conditions, the inability to stimulate the creation of jobs for an expanding labour market, poor and erratic service delivery, rising unemployment, dysfunctional security institutions, and, most importantly, the politics of patronage and state capture. By 2016 the crises had reached such large proportions that the general impression was that South Africa was in a crisis.

Poor economic performance reflected in the declining GDP growth rate from $3.2 \%$ in 2008 to a mere $0.3 \%$ in 2016, a rise in the inflation rate to $6.3 \%$ (from $4.6 \%$ in 2015), and an increase in South Africa's debt from 26.5\% of the GDP in 2008 to $56.7 \%$ in 2018 (CEIC, 2019). The inability to stimulate job creation resulted in an official unemployment rate of $26.6 \%$, with more than a quarter of South Africa's population living under the food poverty line (South African Survey 2019, p. 399). By 2017 social grant recipients had increased to more than 17 million.

Against the background of poor economic conditions and the prevalence of persistent poor and erratic service delivery and unaccountable local governments, an upward trend in 'disorderly' community protests of 50\% in 2006 to $83 \%$ in 2016 were the order of the day. The total number of community protests (with 
most demands about service delivery) reached a high of 377 in 2016 (compared to 164 in 2008), which amounted to a 'rebellion of the poor' (Alexander et al. 2018, pp. $40,35,42)$.

Furthermore, corruption had reached unprecedented heights under the Zuma government. South Africa's score in 2016 was a below-average 4.5 (with 0 being highly corrupt and 10 very clean) (Transparency International 2018). The increase in corruption over the years is also evident in the statistics released by Corruption Watch South Africa. ${ }^{3}$ In 2016, for example, it received 4391 corruption reports compared with 2714 in 2014. It noted in the report that the two most important causes of corruption are 'impunity enjoyed by the politically powerful and rich', which cascades down from the president to cabinet members, provincial premiers and MECs, mayors and local government councillors; and secondly, 'rampant corruption in the leadership of key police units' and the prosecuting authority (Corruption Watch Report 2016).

Alongside the high level of corruption in the country was the emergence of growing evidence that Zuma and his friends, in alliance with the Gupta family, had embarked on capturing the state. The essence of this was facilitating the systematic plundering of public resources by means of appointing Zuma allies to cabinet positions, government departments (particularly the Treasury) and as executives and board members of state-owned enterprises (SOEs) such as Eskom and Transnet. Gupta companies would then receive lucrative contracts from SOEs and government departments, and compliance was rewarded with private payments and promotion. State capture also involved the strategic weakening of the state's law enforcement agencies that might crack down on corruption by replacing the heads of these agencies with Zuma supporters (Chipkin \& Swilling 2018). State capture plunged the economy into further crisis, undermining investor confidence and diverting money away from social delivery programmes (Hosken 2017).

Zuma was recalled by the ANC National Executive on 13 Feb 2018 and he stepped down as president the following day. Ramaphosa, the newly elected president of the ANC, took over. Since assuming the presidency on 18 February, Ramaphosa greatly improved the political atmosphere in the country with the promise of 'a new dawn' and his vow that the days of wanton corruption were over. However, it was widely acknowledged that he held a fragile position in the ANC with a narrow leadership victory of the party, has had to deal with a divided National Executive Council and a divided ANC top six, and has had to use the same ANC to clean up the state when deep-seated corruption is a product of

3 Corruption Watch (2016 Report) defines corruption as 'the abuse of public resources or public power for personal gain'. 
the party (Hamill 2018). In his first eight months in office Ramaphosa brought a sense of urgency to cleaning up government and other institutions. Achievements include management changes in struggling key state-owned enterprises (Eskom, Denel, Transnet, SA Express) as well as a replacement of their boards; the core of the economic clusters - Treasury, Trade and Industry, Economic Development and Mineral Resources - being steered by persons enjoying credibility in both the public and private sectors; new appointments in the security sector, and the suspension of Zuma ally Tom Moyane from the South African Revenue Service (Qobo 2018). A further important appointment was the Judicial Commission of Inquiry into Allegations of State Capture (also known as the Zondo Commission) by Ramaphosa in August 2018. Other ad hoc initiatives and ideas include a job summit (held in October 2018), investor conferences (one held October 2018), special envoys on investment, and a 10-point plan emphasising economic renewal.

However, critics pointed to the fact that the government was still not showing a commitment to undertake the structural reforms required to jump-starting the economy, not offering practical solutions to the high levels of unemployment apart from a proposed job summit, and retaining a bloated civil service and cabinet, which Ramaphosa has shied away from cutting significantly (Mutize 2018).

\section{VOTER PREFERENCES}

Since the first democratic elections in South Africa in 1994, numerous scholarly contributions have provided explanations for vote choice, the static nature of election results (until 2009) as well as the gradual loss of support for the ANC since the 2009 elections.

Voter preference in South Africa's first three democratic elections has been linked to mainly two determinants. Firstly, scholars such as Schlemmer (1994), Lodge (1995), Guelke (1996), Johnson (1996), Friedman (1999) and Letsholo (2005) have all argued that elections have been nothing more than 'a racial census' (Horowitz 1985, p. 326), ${ }^{4}$ whereby electoral choices are shaped by identities, and voters are therefore loyal to the parties representing their identity group. Elections were therefore an act of identity expression and of allegiance to a group. In other words, black people voted for 'black parties' and white people supported 'white parties', while ethnic and regional voting was also evident in, for example, the support for the Inkatha Freedom Party (a predominantly Zulu party) particularly in KwaZulu-Natal (Letsholo 2005, pp. 2-3). Though Davis (2003) acknowledged that voting may be more sophisticated than the racial census argument allows,

4 The seminal work by Donald Horowitz (1985) on politicised ethnicity is considered a benchmark study of ethnic parties, ethnic party dynamics, ethnic voting and elections becoming 'a racial census'. 
he maintained that racial considerations still strongly influenced campaigning (see also Letsholo 2005, p. 6).

However, Taylor and Hoeane (1999, pp. 136, 140) contested this 'racial arithmetic', regarding the purported salience of race and ethnicity in voting behaviour as misconceived. Correlations of categories of race and identity to election results do not prove causation and should be more complex and critically informed interpretations. For them, economic and class considerations can provide better explanations for the ANC's 1999 landslide victory. Also, for Reynolds (1999, p. 176) the high degree of correlation between ethnicity and voting behaviour does not imply that voters are unthinking and irrational people who vote according to their skin colour. In this regard Mattes et al. (1999, pp. 245-246) argue that performance and delivery, a strong election campaign, and the obstacles that opposition parties face in convincing voters to 'take them as a real alternative', also shape the choice of voters. However, voter perception of performance and campaigns is shaped by race, class and ethnicity and the interactions among them. Therefore, as Ferree argues (2006, p. 804), the 'racialized policy images' play a vital role in shaping the voting behaviour of South Africans and, therefore, also their belief about performance and their performance evaluation. Little evidence exists that voters are attracted to parties that are racially exclusive, since polling showed that political partisans loyal to the biggest parties considered their preferred parties to be inclusive. However, perceptions of racial party images influence partisanship and voting behaviour (Schulz-Herzenberg 2012, pp. 144-147).

Party identification (a long-term affective attachment to a party) is also often used to explain voting behaviour in South Africa (Habib \& Naidu, 2006). The ANC has a dominant position in South African politics because it is perceived as a liberation party - the historic bearer of democracy, while opposition parties such as the DA are perceived as parties for whites, and therefore suffer from a legitimacy problem (Letsholo 2005, p. 5). Furthermore, this 'crisis of legitimacy' is used by the ANC as a mechanism to discredit its opponents and present itself as the sole legitimate representative of the interests of South Africans (ibid.). As a consequence, and despite the fact that some voters complain about the way the ANC rules the country, they will continue to vote for it. Partisan loyalty not only provides a cue to voting preferences, but also provides cues for evaluating issues and opposition parties (Dalton 2016). As Mattes (2014, p. 181) puts it: 'party identification resembles a "standing choice" that responds to evolving images of political parties and evaluations of whether or not they are most likely to govern in their [voters'] interest'.

Over the years, partisanship has decreased for all political parties: by 2008, $60 \%$ of the electorate were tied to a specific political party, compared to $86 \%$ in 1994, while the majority of declared partisans were ANC supporters (SchulzHerzenberg 2012, pp. 142-142). 
In the 2009 elections partisan support (particularly for the ANC) based on voter perceptions of the attributes of opposition parties still remained strong, in particular the way they are perceived in terms of racial exclusivity. Voter preference for inclusive parties was visible in these election results, in which the newly formed Cope received 7.4\% support nationally and opinion polls showed that their support came from all demographic groups in the country. On the other hand the DA, still lacking appeal among African voters, could increase its national vote share by only $4 \%$ (Schulz-Herzenberg 2009, p. 44).

However, as shown by national opinion surveys, a growing segment of the population lacks affiliation to any political party: partisanship declined significantly to $45 \%$ in September 2018, while the ANC still enjoyed the most partisan support across all political parties (Schulz-Herzenberg 2019, pp. 61-62). ${ }^{5}$

Rational-choice considerations in terms of valuations of government performance (on socio-economic issues) were hardly taken into account by voters in the first three elections. However, issue-based voting started to play a small role in party support in the 2009 elections (Kersting 2009; Schulz-Herzenberg 2009). Opinion polls at the time showed that the most important election issues for ANC supporters were unemployment (88\%) and poverty $(58 \%)$ while for the DA it was crime $(93 \%)$ and unemployment $(71 \%)^{6}$ (Kersting 2009, p. 126); but, as Schulz-Herzenberg noted, voters tend to evaluate prospectively in terms of 'what they think government will do' (the ANC promised 'a better future for all'). Furthermore, voters considered the situation at national level instead of focusing on their own economic conditions. The higher levels of party identification among ANC supporters also benefitted the party (Schulz-Herzenberg 2009, p. 45). Therefore, although racialised party images and party identification and affiliation were still prominent explanations for voter behaviour by 2009, voters have not been impervious to government performance.

Evaluation on government performance has played an increasingly important role since the 2009 elections: significant job losses and growing perceptions of corruption and nepotism seemed to have impacted on support for the ANC in the 2014 elections (Southall 2014, p. 206). However, evidence that ANC supporters were strongly influenced by performance-based evaluations of the party at both national and local levels was reflected in a national survey conducted after the 2016 local government elections. This was displayed in a loss of trust in the ANC and its leadership as well as the perception of service delivery failures at local

5 In this regard Schulz-Herzenberg $(2019$, p. 61) shows the disparity in the findings of surveys, but nevertheless argues that non-partisan voters constitute a significant proportion of voters.

6 In 2009 corruption was low on the list of problems. Only 17\% of the ANC supporters mentioned this as a main problem, while $49 \%$ of DA supporters saw corruption by government officials as important (Kersting 2009, p. 126). 
level (Justesen \& Schulz-Herzenberg 2018). However, very little is known about the influence of some of the positive performance achievements of the ANC in securing support for the party, in particular the distribution of various types of social grants to some 17 million poor South Africans, who constitute close to a third of the country's population. ${ }^{7}$

The ANC has been accused of using the social grant system as a vote-buying mechanism to win the support of poor voters (News24 17 March 2011; The Star 26 April 2013). This issue became particularly pertinent before the 2014 general elections, when KwaZulu-Natal agriculture MEC Meshack Radebe stated in early April 2014 that those who received social welfare grants but voted for opposition political parties were 'stealing from government' (The Mercury 9 April 2014). It has also been reported that 'the ANC has gone out of its way to market the fact that it has not only expanded social grants, but that social grants are a gift specifically from the ANC government, which can or may be taken away if an opposition party, specifically the DA, comes to power' (DispatchLive, 24 May 2014).

A study undertaken in three poor communities (Doornkop and Riverlea, both in Johannesburg) and Groblersdal (Limpopo) in June 2013 found that grant receipt has some influence in how people vote, but that it is not a driving factor (Graham, Sadie \& Patel 2016). However, this warrants further exploration at a national level, something taken up in the present study.

\section{DATA COLLECTION}

As indicated above, a first national survey was conducted between October and November 2017 (when Zuma was president of the country), while the second was conducted a year later (under the presidency of Ramaphosa). Ipsos Public Affairs, a research consultancy specialising in large-scale surveys, collected the data on our behalf. Five questions were included in Ipsos's Khayabus survey, which is based on a stratified, multi-stage probability sampling procedure. Census estimates were used to define the population; and then, using provincial and municipal estimates, the strata within the larger population. The sample was stratified by province, municipalities, district municipalities, urban and non-urban areas, while the sample selection was randomised using probability proportional to size (PPS). A random walk methodology was used during fieldwork, starting at the points designated by PPS. The sample consisted of metropolitan and rural areas in all nine provinces in South Africa stratified in terms of age, gender and ethnicity.

7 Studies in Argentina (Stokes 2005), Brazil (Hall 2006; 2012 and Hunter \& Power (2007), and Mexico (Magaloni 2014) have all illustrated how social grants have been utilised as election strategies (cited in Graham, Sadie \& Patel 2016). 
In the first survey the sample consisted of 3447 potential voters, while the second consisted of 3580 respondents. Additional biographic and socio-economic information was also obtained, such as age, gender, population group, education level, income and grant receipt and party support 'if there was an election tomorrow'. Face-to-face computer-assisted interviews (CAPIs) were conducted with a questionnaire that was translated into six South African languages.

The dependent variable in the study is the party that respondents intended to vote for in the next election. In order to access the independent or predictor variables, we asked five survey questions in both years. The questions broadly covered the reasons for party support, importance of democratic and socioeconomic rights, government performance (including corruption), trust in institutions and the role of social grants in ANC support.

As shown in Table 1 below, the socio-demographic characteristics of the respondents in the respective 2017 and 2018 samples are very similar. The sample also broadly reflects the composition of the South African population in terms of gender, age, race, urban/rural demographics, expanded unemployment rate and grant recipients.

Table 1: Socio-demographic characteristics of respondents

\begin{tabular}{|l|c|c|}
\hline & $\begin{array}{c}2017 \text { sample, } \\
\text { N=3447 } \\
\%\end{array}$ & $\begin{array}{c}2018 \text { sample, } \\
\text { N=3589 } \\
\%\end{array}$ \\
\hline Male & 50 & 49 \\
\hline Female & 50 & 52 \\
\hline Urban area & 75 & 70 \\
\hline Rural area & 25 & 30 \\
\hline 18-34 years & 49 & 49 \\
\hline 35-59 years & 43 & 41 \\
\hline 60 years and older & 7 & 10 \\
\hline Black & 75 & 77 \\
\hline Coloured & 11 & 10 \\
\hline White & 11 & 3 \\
\hline Indian/Asian & 3 & 37 \\
\hline Less than Grade 12 & 35 & 46 \\
\hline Completed Grade 12 & 50 & 17 \\
\hline Post Grade 12 certificate, diploma or degree & 15 & 58 \\
\hline Less than R8 000p/m & 53 & 16 \\
\hline More than R10 000/pm & 6 & \\
\hline
\end{tabular}




\begin{tabular}{|l|l|l|}
\hline Receive a government grant & 24 & 30 \\
\hline Not working & 19 & 22 \\
\hline Unemployed $^{*}$ & 32 & 33 \\
\hline
\end{tabular}

* Included unemployed looking for work and unemployed not looking for work.

\section{Party Support and Loyalty}

Two questions addressed party support and loyalty. The first was to establish which party respondents would support should an election 'be held tomorrow', while the second question asked respondents to provide their reasons for supporting the particular party. In 2017 respondents were simply asked to provide reasons for their party choice with the interviewee coding responses, whereas in 2018 respondents were asked to provide their top five reasons for party choice in a multiple-choice manner.

The survey undertaken in late 2017 (under the Zuma regime) to a large extent reflected the trend in party support in the local government elections of 2016. The DA's support was still strong (at 22\%), while ANC support remained in the $50 \mathrm{~s}(53 \%)$.

However, the picture started to look different at the end of 2018 with Ramaphosa in power. ANC support (as well as EFF support) increased to the detriment of the DA. On the one hand, there was the election of Ramaphosa as president, and, on the other, incidences within the DA that resulted in a loss of support of the party. These include tweets by Helen Zille (former leader of the party and premier of the Western Cape) that the legacy of colonialism was not all negative, and a breakdown in the relations between Patricia de Lille (mayor of Cape Town) and the DA. The party terminated her membership (without due process) in May 2018 on account of mismanagement, favouritism and nepotism.

The change in party support over the two surveys seems to underline the fact that a strong affiliation to a specific political party is waning. However, a significant number of voters still supported the ANC despite its poor performance under Zuma.

Table 2: Party support

\begin{tabular}{|l|c|c|}
\hline & $\begin{array}{c}\mathbf{2 0 1 7} \\
\%\end{array}$ & $\begin{array}{c}\mathbf{2 0 1 8} \\
\%\end{array}$ \\
\hline ANC & 53 & 56 \\
\hline DA & 22 & 13 \\
\hline EFF & 6 & 9 \\
\hline
\end{tabular}




\begin{tabular}{|l|c|c|}
\hline Other parties? & 8 & 13 \\
\hline Would not vote & 5 & 4 \\
\hline Refuse to answer & 6 & 5 \\
\hline Total & 100 & 100 \\
\hline
\end{tabular}

The two main reasons for party choice in both the 2017 and 2018 surveys for the ANC, DA and EFF supporters are that are that they believed 'the party will bring a better life' (for the full sample - 65\% in 2018 and 32\% in 2017) and that 'the party brought freedom and democracy to South Africa' (for the full sample-62\% in 2018 and $35 \%$ in 2017). 'Trust in the party' came up as the third main reason provided by all three parties. With regard to ANC voters, 'trust in the party' was provided as a reason for supporting the ANC by $32.2 \%$ in 2017, while $58.8 \%$ noted trust as an important reason in 2018 - therefore, indicating a substantial increase in trust in the party under Ramaphosa as party leader.

Racial considerations (being 'a party for blacks' or 'a party for whites') have been by far the lowest consideration for supporters of each of the three parties. Instead, the consideration that it is 'a party for all' was provided as the most common reason for party support (compared with a 'party for blacks' or a 'party for whites').

\section{Trust, Performance and Democracy}

While scholars underline the importance of democratic institutions and processes such as elections in sustaining democracies, they usually emphasise citizen support for not only democracy but also its institutions - what Linz and Stepan (1997, pp. 15-17) refer to as 'attitudinal' support. Bratton and Cho (2006, p. 3) underline that people's perceptions in the domain of politics have a bearing on their expectations and behaviour. It matters 'just as much - if not more - than reality. That which people think is true, including judgments about present conditions or past performance and expectations for the future, is a central motivation for behaviour.'

One of the main functions of the governing political party is to organise government institutions and implement its policies or programmes. How voters perceive the performance of these institutions, which in effect is 'managed' by the governing party, is an important determinant of whether voters will again support the governing party in a future election. However, it is also likely that bad performance and mistrust may, due to very strong party loyalty, have little bearing on voters' choice and may suggest a lack of a rational choice being exercised. 
Equally important is establishing respondents' trust (confidence) in their political institutions. There are many explanations, based on different theoretical rationales, as to why people trust or distrust their institutions; these include perceived institutional performance and effectiveness. Trust in political institutions is closely linked to perceptions of political performance (good governance) and government delivery (Bratton et al. 2005, p. 67). Citizens' trust in the political system is tied to increasing or maintaining their well-being. Trust is thus something that does not come naturally, it has to be earned. Trust in institutions such as the legal system, police, and civil service depends heavily on their ability to solve the problems they are expected to address (Listhaug \& Wiberg 1995, p. 302). Put simply, trust is present when citizens perceive that the government delivers goods and services. However, trust judgments are also influenced by performance of the incumbent president, the personal qualities of the leader, dissatisfaction with positions taken by political parties, and economic performance (Levi \& Stoker 2000, p. 480). Also, the local social and political context of citizens, coupled with their political perceptions and values, influence their trust in political parties and government institutions. It therefore also accounts for the variations in trust in political institutions (Levi \& Stoker 2000, p. 481).

In their empirical study, Anderson and Tverdora (2003, p. 91) found that corruption $^{8}$ and performance shape trust in political institutions. Corruption is an important indicator of government performance, which also negatively affects people's evaluation of political institutions and voters' political allegiance. Thus, corruption 'is an important component of government performance people use to judge political institutions'. Therefore, 'in more corrupt democracies citizens report lower levels of satisfaction with the performance of their political systems and trust in civil servants compared to people in democracies that are cleaner' (Anderson \& Tverdora 2003, p. 104).

For Catterberg and Moreno (2005, pp. 31, 42, 46) performance is also 'an inherent element of political trust', which is tied to the provision of individual well-being. However, political trust is undermined by a willingness to justify acts of corruption in society. Trust is also positively related to democratic attitudes.

Rational choice theory (which assumes that voters weigh costs and benefits before voting) can be used to explain the link between voting behaviour and perceptions of corruption. Not only are voters less likely to vote when the government is perceived as corrupt, but perceived corruption has affected the fortunes of political leaders - they have for example received fewer votes after

8 Defined by Sandholtz and Koetzle (2000, p. 32) as 'the misuse of public office for private gain', as opposed to private corruption, which raises the political issues of governance, political authority, legitimacy, democracy and state-society relations. 
being charged with corruption, which has thus cost them their popularity (Caillier 2010, p. 1018).

\section{Variables and Analysis}

As mentioned, the dependent variable in the study is the party that respondents intended to vote for in the next election. It was set as 1 if the respondents said that they would vote for the ANC in the next election, and 0 if they said that they would vote for an opposition party. Those who refused to answer or indicated that they would not vote were excluded.

A number of independent variables were selected that are theoretically relevant in the study of voting behaviour in South Africa. These are: trust in government institutions, the prevalence of corruption, government performance, democratic values, socio-economic well-being and social grants.

Cross-tabulations were run to ascertain which independent variables were significantly associated with voter choice. Thereafter, logistic regression was used to predict the impact of the three primary independent variables on voter choice. These are: perceptions of trust, the importance of democracy and socio-economic well-being, and perceptions of corruption.

Trust in institutions: To measure respondents' trust in institutions, an average score across the seven questions relating to trust in institutions were calculated. An explanatory factor analysis was done, which resulted in one factor. No reverse scoring was necessary. The Kaiser-Meyer-Olkin measure of sampling adequacy was used to check whether the items were suitable for factor analysis. The KaiserMeyer-Olkin value measured 0.9, exceeding the recommended value of 0.6 (Kaiser 1974) and Bartlett's Test of Sphericity (Bartlett 1954) reached statistical significance. The results supported the factorability of the correction matrix. This new variable was termed 'governance'. A check for weak items was done by using the antiimage correlations. All items had measures of sampling adequacy (MSA) values above 0.6 and therefore it was not necessary to remove any item from the factors constructed. We inspected the commonalities at extraction test. Low values (less than 0.3 ) could indicate that an item does not fit well with the other items in its component. All values exceeded 0.3.

The importance of democratic rights and socio-economic well-being: Using the questions 'which one is closest to your opinion, even if you don't fully agree, please choose that is most important to you: 1) Democratic rights like voting, access to courts, freedom of speech and expression or 2) socio-economic wellbeing, meeting your basic needs, jobs, income, housing etc'. If socio-economic well-being was more important, a 1 was assigned. 
Perceptions of corruption: Using the question 'There is a lot of talk about corruption in our country. Do you think that corruption has increased in South Africa in the past few years?', a value 1 was assigned if the respondent answered yes and 0 if the respondent answered no.

Variables were included to control for age, population group, household income level, residential area, gender, education level, grant receipt versus nonreceipt and whether recipients answered that their reason for party choice was that they received a grant from the government, which they feared they would not receive if another party came to power.

A test for multicollinearity was also done to confirm that the correlation between variables in the model was not too high. VIF (variance inflation factor) and tolerance were also measured. The VIF values were close to 1 , which is acceptable. There were no concerns of collinearity in the model and the regression coefficients rendered were indeed the factors that were likely predictors of voter choice.

In addition to the above basic model, a second model with additional variables was run. This was where respondents indicated that the reason for party choice was that they believed the party 'brought freedom and democracy' as well as whether respondents supported land expropriation with or without compensation. Furthermore, trust in Ramaphosa was added to the model as a separate variable, and the trust index was amended to exclude this variable.

\section{FINDINGS}

\section{Importance of Social Grants}

In terms of party choice (see above) a comparison was drawn between those who received a government grant and those who did not receive such a grant. Of the respondents who received a grant, in both surveys $73 \%$ said they would vote for the ANC, while $27 \%$ said that they would vote for one of the opposition parties. Of those who did not receive a grant, $61 \%$ (2017) and 66\% (2018) said they would vote for the ANC and 39\% (2017) and 34\% (2018) for an opposition party. Using Fisher's Exact Test, this difference was statistically significant $(\mathrm{P}=0.000$ in 2017 and $\mathrm{P}=0.001$ in 2018). Therefore, grant recipients are more likely than non-recipients to vote for the ruling ANC. However, using Cohen's (1988) criteria of effect sizes, the magnitude of the effect is small (Phi=0.107 in $2017 \& \mathrm{Phi}=0.064$ in 2018). This finding is in line with the limited study by Patel et al. (2014), who reported that grant receipt plays some role in voter choice but is not a driving factor.

\section{Importance of Democratic Rights and Socio-Economic Well-Being}

When respondents were asked which they consider to be more important, democratic rights or socio-economic well-being, 45\% and 59\% (2017 and 2018 
respectively) said economic well-being, while $43 \%$ and $27 \%$ said democratic rights. The remaining percentage said that they did not know which they considered more important. This increase from 2017 to 2018 in the emphasis on socio-economic well-being may hold implications for future elections and democracy in the country. These results seem to underline a trend highlighted by Lekalake (2016, p. 1) based on a 2015 survey by Afrobarometer, which shows that outright support for democracy has declined since 2011 and that the provision of basic services is more important than elections to the majority of South Africans. It also resonates with Claude Ake's caution two decades ago that "The feasibility of democracy in Africa will depend crucially on how it relates to the social experience of Africans and how far it serves their social needs" (Ake 2003 (reprint), p. 75).

\section{Trust in Institutions}

As seen in Table 3 below, trust in President Zuma in October/November 2017 was at a low of $26 \%$, with levels of trust considerably higher in, for example, the courts (53\%), the Department of Social Development (52\%), parliament (45\%) and the police (45\%). In October/November 2018 the picture changed dramatically, especially in terms of trust in the president. Ramaphosa was trusted by $62 \%$ of respondents compared to the mere 26\% that trusted Zuma. With Ramaphosa as president, trust in parliament also increased (from 45\% in 2017 to 48\% in 2018).

Table 3: Trust in institutions

\begin{tabular}{|c|c|c|c|c|c|c|c|c|c|}
\hline & \multirow{2}{*}{\multicolumn{2}{|c|}{$\begin{array}{c}\text { Trust } \\
{ }^{*} \text { Very / } \\
\text { extremely likely } \\
2017 \% 2018\end{array}$}} & \multicolumn{2}{|c|}{$\begin{array}{c}\text { Trust } \\
{ }^{* *} \text { Not / at all } \\
\text { likely }\end{array}$} & \multicolumn{2}{|c|}{$\begin{array}{c}\text { Trust } \\
\text { Neither/nor }\end{array}$} & \multicolumn{3}{|c|}{ Total } \\
\hline & & & $2017 \%$ & 2018 & $2017 \%$ & 2018 & 2017 & $\%$ & 2018 \\
\hline $\begin{array}{l}\text { President } \\
\text { Zuma (2017) } \\
\text { Ramaphosa (2018) }\end{array}$ & 26 & 62 & 56 & 18 & 18 & 20 & 100 & & 100 \\
\hline Parliament & 45 & 48 & 29 & 26 & 26 & 26 & 100 & & 100 \\
\hline $\begin{array}{l}\text { Dept of Social } \\
\text { Development }\end{array}$ & 52 & 54 & 21 & 21 & 27 & 25 & 100 & & 100 \\
\hline SA Police & 45 & 48 & 25 & 29 & 30 & 23 & 100 & & 100 \\
\hline Courts & 53 & 51 & 21 & 25 & 26 & 24 & 100 & & 100 \\
\hline $\begin{array}{l}\text { SA Social Security } \\
\text { Agency }\end{array}$ & 52 & 62 & 21 & 18 & 27 & 20 & 100 & & 100 \\
\hline Media & 53 & 46 & 19 & 29 & 28 & 25 & 100 & & 100 \\
\hline
\end{tabular}

${ }^{*}$ Combined very likely and extremely likely ${ }^{* *}$ combined not at all likely and not likely 


\section{Perceptions of Corruption}

The increase in corruption on an annual basis has been perceived by a large majority of South Africa's population in both the 2017 and 2018 surveys. However, despite the fact that Ramaphosa had been in power for only eight months when the survey was conducted, his presence as president showed a slight drop in the proportion of South Africans that were of the opinion that corruption had increased 'in the last year' (76\% in 2017 down to 72\% of respondents in 2018). In both years $6 \%$ reported that they did not know whether corruption was increasing or not.

\section{Regression Model Results}

According to the logistic regression model based on the 2017 survey (see Table 4 below), all the predictor variables - that is, trust in institutions, importance of democratic rights and socio-economic well-being, and perceptions of corruption - were shown to be significant in determining whether a respondent is likely to vote for the ANC or for an opposition party. Age, population group, education, gender, and whether respondents said they voted for a party because they received a grant and were afraid that the grant would not be provided by another party, were all shown to be statistically significant. Household income, area they reside in, employment status and receipt of a grant from the government were not found to contribute significantly to the model. ${ }^{9}$

Table 4: Logistic regression analysis from 2017 survey

\begin{tabular}{|c|c|c|c|c|c|c|c|c|}
\hline \multicolumn{9}{|c|}{ Variables in the Model } \\
\hline & \multirow[t]{2}{*}{ Beta } & \multirow[t]{2}{*}{$\begin{array}{l}\text { Std. } \\
\text { Error }\end{array}$} & \multirow[t]{2}{*}{ Wald } & \multirow[t]{2}{*}{ Df } & \multirow[t]{2}{*}{ P-value } & \multirow{2}{*}{$\begin{array}{l}\text { Odds } \\
\text { Ratio } \\
\text { Lower }\end{array}$} & \multicolumn{2}{|c|}{$\begin{array}{l}95 \% \text { C.I. for } \\
\text { Odds Ratio }\end{array}$} \\
\hline & & & & & & & Upper & \\
\hline Trust & 0,335 & 0,071 & 22,067 & 1 & 0,000 & 1,398 & 1,216 & 1,608 \\
\hline $\begin{array}{l}\text { Socio- } \\
\text { economic } \\
\text { well-being }\end{array}$ & $-0,493$ & 0,130 & 14,271 & 1 & 0,000 & 0,611 & 0,473 & 0,789 \\
\hline Corruption & $-0,595$ & 0,176 & 11,389 & 1 & 0,001 & 0,552 & 0,391 & 0,779 \\
\hline Age & 0,015 & 0,006 & 7,660 & 1 & 0,006 & 1,015 & 1,004 & 1,027 \\
\hline White & $-3,143$ & 0,270 & 135,046 & 1 & 0,000 & 0,043 & 0,025 & 0,073 \\
\hline
\end{tabular}

9 The software used for both surveys was IBM SPSS Statistics version 25. 


\begin{tabular}{|l|c|c|r|r|r|r|r|r|}
\hline $\begin{array}{l}\text { Indian/ } \\
\text { Asian }\end{array}$ & $-2,783$ & 0,451 & 38,093 & 1 & 0,000 & 0,062 & 0,026 & 0,150 \\
\hline Coloured & $-2,348$ & 0,227 & 107,242 & 1 & 0,000 & 0,096 & 0,061 & 0,149 \\
\hline Income & $-0,001$ & 0,011 & 0,017 & 1 & 0,897 & 0,999 & 0,976 & 1,021 \\
\hline Area & $-0,178$ & 0,165 & 1,173 & 1 & 0,279 & 0,837 & 0,606 & 1,155 \\
\hline Not working & $-0,205$ & 0,211 & 0,945 & 1 & 0,331 & 0,814 & 0,538 & 1,232 \\
\hline Unemployed & $-0,087$ & 0,196 & 0,200 & 1 & 0,655 & 0,916 & 0,624 & 1,345 \\
\hline Education & $-0,184$ & 0,068 & 7,338 & 1 & 0,007 & 0,832 & 0,728 & 0,950 \\
\hline Gender & $-0,285$ & 0,136 & 4,372 & 1 & 0,037 & 0,752 & 0,576 & 0,982 \\
\hline $\begin{array}{l}\text { Grant } \\
\text { receipt }\end{array}$ & 0,065 & 0,181 & 0,128 & 1 & 0,721 & 1,067 & 0,749 & 1,520 \\
\hline $\begin{array}{l}\text { Fear of loss } \\
\text { of grant }\end{array}$ & 0,987 & 0,227 & 18,896 & 1 & 0,000 & 2,684 & 1,720 & 4,190 \\
\hline Constant & 1,909 & 0,631 & 9,148 & 1 & 0,002 & 6,744 & & \\
\hline
\end{tabular}

Using the 2018 survey (see Table 5), trust in institutions and perceptions of corruption were shown to be statistically significant in determining whether respondents would vote for the ANC or for an opposition party. Age, population group, income and whether they agreed that they were 'afraid that if another party comes to power social grants will stop' were all shown to be statistically significant. Area of residence, employment, education, gender and grant receipt were not significant.

Table 5: Logistic regression analysis from 2018 survey

\begin{tabular}{|l|c|c|c|c|c|c|c|c|}
\hline \multicolumn{7}{|c|}{ Variables in the Model } \\
\hline & Beta & $\begin{array}{c}\text { Std. } \\
\text { Error }\end{array}$ & Wald & df & P-value & $\begin{array}{c}\text { Odds } \\
\text { Ratio } \\
\text { Lower }\end{array}$ & $\begin{array}{c}\text { 95\% C.I. } \\
\text { for Odds Ratio }\end{array}$ \\
\hline \begin{tabular}{l} 
Trust \\
\hline $\begin{array}{l}\text { Socio- } \\
\text { economic } \\
\text { well-being }\end{array}$
\end{tabular} & 0,610 & 0,072 & 71,518 & 1 & 0,000 & 1,840 & 1,597 & 2,119 \\
\hline
\end{tabular}




\begin{tabular}{|l|c|c|c|c|c|c|c|c|}
\hline Corruption & $-0,519$ & 0,150 & 11,941 & 1 & 0,001 & 0,595 & 0,443 & 0,799 \\
\hline Age & 0,019 & 0,005 & 13,770 & 1 & 0,000 & 1,019 & 1,009 & 1,029 \\
\hline White & $-2,847$ & 0,223 & 162,528 & 1 & 0,000 & 0,058 & 0,037 & 0,090 \\
\hline $\begin{array}{l}\text { Indian/ } \\
\text { Asian }\end{array}$ & $-1,785$ & 0,431 & 17,191 & 1 & 0,000 & 0,168 & 0,072 & 0,390 \\
\hline Coloured & $-2,023$ & 0,191 & 111,721 & 1 & 0,000 & 0,132 & 0,091 & 0,192 \\
\hline Income & $-0,020$ & 0,008 & 6,640 & 1 & 0,010 & 0,980 & 0,965 & 0,995 \\
\hline Area & $-0,081$ & 0,144 & 0,318 & 1 & 0,573 & 0,922 & 0,695 & 1,223 \\
\hline Not working & 0,022 & 0,178 & 0,015 & 1 & 0,902 & 1,022 & 0,722 & 1,448 \\
\hline Unemployed & $-0,131$ & 0,160 & 0,667 & 1 & 0,414 & 0,877 & 0,641 & 1,201 \\
\hline Education & 0,073 & 0,055 & 1,761 & 1 & 0,185 & 1,075 & 0,966 & 1,197 \\
\hline Gender & 0,150 & 0,124 & 1,457 & 1 & 0,227 & 1,162 & 0,911 & 1,483 \\
\hline $\begin{array}{l}\text { Grant } \\
\text { receipt }\end{array}$ & $-0,150$ & 0,147 & 1,044 & 1 & 0,307 & 0,861 & 0,646 & 1,147 \\
\hline $\begin{array}{l}\text { Fear of loss } \\
\text { of grant }\end{array}$ & 0,750 & 0,123 & 37,520 & 1 & 0,000 & 2,118 & 1,666 & 2,693 \\
\hline Constant & $-1,418$ & 0,542 & 6,845 & 1 & 0,009 & 0,242 & & \\
\hline
\end{tabular}

Trust (particularly trust in the president), perceptions of corruption, age, population group and fear of grants discontinuing if opposition parties come to power were significant predictors of voter choice in both surveys.

In both surveys, the higher the level of trust in institutions, the more likely the respondent would vote for the ANC. In 2017, the odds of voting for the ANC increased by 1398 (or 2\%) for each additional unit of trust reported. In 2018, the odds of a respondent voting for the ANC increased by 1.84 (or $84 \%$ more likely) for each additional unit of trust in institutions the respondent held, all other factors being equal. We found that in 2017, $58 \%$ of the total variance in the model is explained by the factor constructed for trust. The variance explained by trust reduced slightly to $53 \%$ in 2018.

Respondents who believed that corruption had increased in the last year were less likely to vote for the ANC than those who did not believe that corruption had increased. If respondents believed that corruption had increased, they were 0.5 (or 50\%) in 2017 and 0.595 (or 40.5\%) in 2018 less likely to vote ANC than those who did not believe that corruption had increased in the past year (all else being equal). 
Another finding is that older respondents are more likely to vote for the ANC than younger respondents. For each additional year in age, the odds of a respondent voting for the ANC increased by a factor of 1019 , all other factors being equal. In other words, over a ten-year difference in age, the likelihood of choosing the ANC increases by 20\%. In 2017, a respondent was 1015 times likelier to choose the ANC than someone who was a year younger.

In the regression analysis from both surveys, whether respondents actually receive a grant or not is not a significant determinant of voter choice. In contrast, the fear of losing a grant does matter. For respondents who agree with the statement they are 'afraid that if another party comes to power social grants will stop', the odds of voting for the ANC increased by a factor of 2118 (or 118\%) compared to those who disagreed with the statement. Therefore, those who agree with the statements are more than twice as likely to vote for the ANC than those who disagree, all other things being equal.

\section{Regression Results with Additional Variables (model 2)}

In this model, trust in institutions, amended to exclude trust in the presidency, is not significant. However, trust in the president specifically increased from that for Zuma in 2017. For each unit of trust in the president (on a five-point scale), the chances of preferring the ANC over an opposition party increased by $58.9 \%$. This means that between those who strongly distrust the president and those who strongly trust President Ramaphosa, there is a tenfold increase in the likelihood of choosing the ANC in the 2019 elections. Only 9\% of respondents said that they were extremely distrustful of Ramaphosa, as opposed to $39 \%$ who were extremely distrustful of Zuma.

However, the results for this model are similar to the results above, where Ramaphosa is subsumed in the trust index. The magnitudes of the effect of perception of corruption, age, race and fear of loss of grant are all significant in determining the likelihood of choosing the ANC or an opposition party.

The results vary with the other additional variables added in model two. The 2017 survey found that the party that 'brought freedom and democracy' provided as a reason for supporting the party was not significant in the logistical regression. In the 2018 survey, the variable is significant, with those providing this reason for their party choice to be $81 \%$ likelier to choose the ANC over an opposition party, compared to those who did not offer this as a reason for party choice, all other factors being equal. Whether respondents agreed that they support land expropriation with or without compensation was not significant in voter preferences. 
Table 6: Summary of the logistic regression analysis over two surveys

\begin{tabular}{|c|c|c|c|}
\hline Variable & $\begin{array}{l}\text { Significant } \\
\text { predictor in } \\
\text { both surveys }\end{array}$ & $\begin{array}{c}\text { Non-significant } \\
\text { predictor in } \\
\text { both surveys }\end{array}$ & $\begin{array}{c}\text { Significant } \\
\text { predictor in } \\
\text { one survey bu } \\
\text { not the other }\end{array}$ \\
\hline Trust in president & * & & \\
\hline Perception of corruption & * & & \\
\hline Age & * & & \\
\hline Population group & * & & \\
\hline $\begin{array}{l}\text { Fear grants will discontinue if } \\
\text { another party comes to power }\end{array}$ & * & & \\
\hline Employment & & * & \\
\hline Grant receipt & & * & \\
\hline Socio-economic well-being & & & * \\
\hline Income & & & * \\
\hline Education & & & * \\
\hline Gender & & & * \\
\hline $\begin{array}{l}\text { 'Party brought freedom and } \\
\text { democracy' }\end{array}$ & & & * \\
\hline
\end{tabular}

\section{CONCLUSION}

The two surveys, one conducted 14 months after the local government elections in 2016 (with Zuma still in power) and the second conducted six months before the general elections in 2019 (with Ramaphosa as new president), provide important insights into the factors that drive the choice of vote of South Africans. The intention of the surveys was not to predict the outcome of the 2019 general elections, but rather to attempt to understand what drives potential South African voters to support the party of their choice. The prevailing socio-economic and political environment was characterised by high levels of public corruption, accusations of state capture by the president and his allies within the governing ANC, insufficient delivery of basic services, and increasingly high levels of poverty and unemployment which result in the provision of various types of social grants to over 17 million South Africans. It was therefore important to establish the extent to which these aspects had an impact on the party choice of voters and their trust in various public institutions. 
What has become evident is that although party identification or partisan loyalty still plays an important role in vote choice, South African voters increasingly base their choice of party on rational considerations and it is clear that they are no longer impervious to government performance. From both surveys it is evident that trust in the president of the country, in particular, is an important predictor of choice of a party. The leadership changes in the ANC accounted to a large extent for the increase in ANC support in the second survey. It therefore suggests that a loss of trust in Zuma (as a result of the high level of corruption and state capture associated with his rule) also resulted in a loss of faith in the party. Trust in Ramaphosa and thus his popularity has also helped the ANC: the proportion of people who trusted the party has risen significantly since the first survey, when Zuma was in power. Voters who did not support the ANC in the first survey seemed to return to supporting the ANC at the end of 2018 when Ramaphosa was president. Despite the fact that he had been in power for only eight months, Ramaphosa gave voters the hope of a cleaner government and restored some confidence in the party that brought freedom and democracy to South Africa.

It also appeared that some rational considerations explain the loss of voter support for the DA, as recorded in the second survey. These include some serious errors made by the party leadership, including the Zille tweets on colonialism and the controversy surrounding Patricia de Lille, which may have driven away some black and coloured supporters.

The desire for socio-economic well-being as well as the hope for a better life was selected by the majority of respondents (65\%) as one of the main reasons for party choice. (This doubled between the first and second surveys.) Furthermore, although social grant receipt does not influence voting behaviour, the fear of losing a grant should another party come to power was a significant predictor of voter choice in both the 2017 and 2018 surveys.

Socio-demographic factors also emerged as predictors of voter choice. Older voters and those with a lower income appear more likely to prefer the ANC. Given the high proportion constituted by the youth (if they indeed actually go to vote), this can have an impact on the outcome of elections and particularly on support for the ANC. Furthermore, there is a changing demographic composition of voters with large numbers of the youth becoming eligible voters every year. Therefore, party identification is likely to become less important in explaining voter choice if young voters participate in elections in large numbers.

Although race is still a feature in party support, there is little evidence in both surveys that parties attract voters because they are racially exclusive. Instead, the results show that most supporters of the three larger parties (ANC, DA and EFF) considered their parties to be inclusive and that their support of the party is not 
because it is a party for blacks or whites. Nevertheless, racialised party images still appear to shape voter choice.

In conclusion, it is evident from both surveys that multiple factors were found to have an influence on how people vote. Also, that leadership evaluation is likely to be pivotal in the vote choice of South Africans in future elections.

The stronger support for the ANC in the 2019 elections, which took place six months after the 2018 survey was conducted, seemed to suggest that the same positive feeling towards Ramaphosa (as reflected in the 2018 survey) prevailed. As scholars and commentators pointed out after the 2019 elections, throughout the election campaign polls showed Ramaphosa's personal popularity was higher than the collective popularity of the ANC. In addition, the relatively high percentage of voters who split their vote (voting for one party nationally and for another provincially) was interpreted as people's trust in Ramaphosa at a national level and a 'belief that he can take the ANC to another level', while they are not happy with the party at provincial level (Mathekga as quoted by Dylan 2019). As also acknowledged after the elections by the ANC's elections head Fikile Mbalula, if another candidate had led the ANC the party's support might have dropped to $40 \%$ in the national poll (instead of the 58\% support it received) (TimesLIVE 9 May 2019). ${ }^{10}$

Therefore, the performance of Ramaphosa is critical in shaping the choice of future party support. If he does not manage to reduce the level of corruption (as perceived by the people), to end the impunity of people involved in state capture, and does not manage to bring about economic growth and job creation, voters are likely to turn away from supporting the ruling party in future elections.

\section{Acknowledgements}

Our thanks and appreciation to Megan Bryer and Jacklyn de Klerk for the statistical analysis. This research was supported by the DST/NRF South African Research Chair in Welfare and Social Development and the University of Johannesburg Research Fund (central and faculty).

10 Although it seems that the positive mood regarding Ramaphosa in the 2018 survey has been echoed in the 2019 election results, the 2018 survey was conducted among all South Africans of voting age, while the universe of the 2019 elections consisted of only those South Africans that voted in the elections which represents a mere $49.3 \%$ of the eligible VAP. 


\section{----- REFERENCES}

Ake, C 2003, The Feasibility of Democracy in Africa, CODESRIA, Dakar, Senegal.

Alexander, P et.al. 2018, 'Frequency and turmoil: South Africa's community protests 2005-2017', SA Crime Quarterly, vol. 63, pp. 27-42.

Anderson, CJ \& Tverdova, YV 2003, 'Corruption, Political Allegiances, and Attitudes Toward Government in Contemporary Democracies', American Journal of Political Science, vol. 47, no.1, pp. 91-109.

Booysen, S 2015, Dominance and Decline: The ANC in the time of Zuma, Wits University Press, Johannesburg.

Bratton, M, Mattes, R \& Giyimah-Boadi, E 2005, Public opinion, democracy and market reform in Africa, Cambridge University Press, Cambridge.

Bratton, M \& Cho, W 2006, 'Where is Africa going? Views from below', Afrobarometer, Working Paper no. 60 (May).

Caillier, J 2010, 'Citizen Trust, Political Corruption, and Voting Behavior: Connecting the Dots', Politics and Policy, vol. 38, no. 5, pp. 1015-1035.

Catterberg, G \& Moreno, A 2005, 'The Individual Bases of Political Trust: Trends in New and Established Democracies', International Journal of Public Opinion Research, vol.18, no.1, pp. 31-48.

CEIC, 2019, 'South Africa Government Debt: \% of GDP'. Available at: https://www. ceicdata.com/en/indicator/south-africa/governmetn-debt--of-nominal-gdp

Chipkin, I \& Swilling, M 2018, Shadow State: The Politics of State Capture, Wits University Press (EPUB), Johannesburg.

Corruption Watch, Annual Report, 2016, Volume 1, Issue 1. Available at: https:// www.corruptionwatch.org.za/wp-content/uploads/2017/2/CorruptionWatch-Annual-Report-27-02-2017-Low-Res-Version.pdf

Dalton, RJ 2016, 'Party Identification and Its Implications', Oxford Research Encyclopedia. Available at: Doi: 10.1093/acrefore/9780190228637.013.72

Davis, G 2003, 'The Electoral Temptation of Race in South Africa: Implications for the 2004 Election', Transformation: Critical Perspectives on Southern Africa vol.53, no.1, pp. 4-28.

DispatchLive, 2014, 'Zuma badly misreads old, rural party result' 24 May. Available at: https://www.dispatchlive.co.za/news/opinion/2014-05-24-zuma--badlymisreads-old-rural-party-result/

Dylan, J 2019, 'Support for Ramaphosa not matched by provincial support for the ruling party' 15 May. Available at: https://www.dailymaverick.co.za/article/201905-15-support-for-ramaphosa-not-matched-by-provincialpsupport-for-theruling-party

ECPR 2019, 'Comparing Local Elections and Voting: Lower Rank, Different Kind... or Missing Link?' Workshop Abstract. Available at: https://ecpr.eu/Events/ PanelDetails.aspx?PanelID=7676\&EventID=121 
Ferree, K E 2006, 'Explaining South Africa's Racial Census', The Journal of Politics, vol. 68, no. 4, pp. 803-815.

Friedman, S 1999, 'Who We Are: Voter Participation, Rationality and the 1999 Election', Politikon, vol. 26, no.2, pp. 213-223.

Graham, V, Sadie, Y \& Patel, L 2016, 'Social grants, food parcels and voting behaviour: a case study of three South African communities', Transformation: Critical Perspectives on Southern Africa, vol. 91, pp. 106-135.

Guelke, A 1996, 'Dissecting the South African Miracle: African Parallels', Nationalism and Ethnic Politics, vol. 2, no.1, pp.141-154.

Habib, A \& Naidu, S 2006, 'Race, Class and Voting Patterns in South Africa's Electoral System: Ten Years of Democracy', African Development, vol.31, no.3, pp. 81-92.

Hamill, J 2018, 'Why the ANC itself is the chief impediment to Ramaphosa's agenda', The Conversation 14 December. Available at: http://theconversation.com/ why-the-anc-itself-is-the-chief-impediment-toramaphosas-agenda-108781

Harris, M 2012, 'The methodology of polling public opinion in South Africa: Measuring the pulse of the people' in HA Thuynsma (ed), Public Opinion and Interest Group Politics - South Africa's Missing Links?, Africa Institute, Pretoria. Horowitz, DL 1985, Ethnic Groups in Conflict, University of California Press, Berkley. Hosken, G 2017, 'The effect of State Capture on the man in the street', Sunday Times -TimesLIVE 7 June. Available at: https://www.timeslive.co.za/politics/201706-07-the effect-of-state-capture-on-the-man-in-the-street-/

Johnson, RW 1996, 'The 1994 Election: Outcome and Analysis', in RW Johnson \& L Schlemmer (eds), Launching Democracy in South Africa: The First Open Election, April 1994, Yale University Press, New Haven.

Justesen, MK \& Schulz-Herzenberg, C 2018, 'The Decline of the African National Congress in South Africa's 2016 Municipal Elections', Journal of Southern African Studies, vol. 44, no. 6, pp. 1133-1151.

Kersting, N 2009, 'Voting Behaviour in the 2009 South African Election', Afrika Spectrum, vol. 44, no. 2, pp. 125-133.

Lekalake, R 2016, 'Support for democracy in South Africa declines amid rising discontent with implementation', Afrobarometer Dispatch, No. 71, (9 February), pp.1-9. Available at: https://afrobarometer.org/sites/default/files/ publications/Dispatches/ab_r6_dispatchno71_south_africa_perceptions_ of_democracy.pdf

Letsholo, S 2005, 'How the ANC Won the 2004 Elections: Perspectives on Voting Behaviour in South Africa', EISA Occasional Paper No. 31 (April), EISA, Auckland Park.

Levi, M \& Stoker, L 2000, 'Political Trust and Trustworthiness', Annual Review of Political Science, vol. 3, pp. 475-507.

Linz, J \& Stepan, A 1997, 'Toward consolidated democracy', in L Diamond, 
M Plattner, \& Y Chu (eds), Consolidating the Third Wave democracies: themes and perspectives, Johns Hopkins University Press, Baltimore.

Listhaug, O \& M Wiberg 1995, 'Confidence in political and private institutions, in H Klingemann, \& D Fuchs (eds), Citizen and the state, Oxford University Press, Oxford.

Lodge, T 1995, 'The South African General Election, April 1994: Results, Analysis and Publications', African Affairs, no. 94, no. 377, pp. 471-500.

Maserumule, MH \& Ndletyana, M 2016, 'Unmasking the Outcomes of the 2016 Local Government Elections' (Editorial Essay), Journal of Public Administration, vol. 51, no. 3.1, pp. 442-449.

Mattes, R 2014, 'The 2014 election and South African democracy', in C SchulzHerzenberg, \& R Southall, Election 2014 - South Africa, Jacana Media, Johannesburg.

Mattes, R, Taylor, H \& Africa, C 1999, 'Judgement and Choice in the 1999 South African Election', Politikon, vol. 26, no.2, pp. 235-247.

Mutize, M 2018, 'Patience with Ramaphosa's presidency is waning' 5 June, The Conversation. Available at: https://theconversation.com/patience-withramaphosas-presidency-is-waning-among-south-africans-97467

News24, 2011, 'Grants shouldn't be 'political bribes', 17 March. Available at: http:// www.news24.com/SouthAfrica/Politics/Grants-shouldnt-be-political-bribes

Patel, L, Sadie, Y, Graham, V, Delany, A. \& Baldry, K 2014, Voting Behaviour and the Influence of Social Protection: A study of voting behaviour in three poor areas in South Africa, University of Johannesburg Centre for Social Development, Johannesburg.

Qobo, M 2018, 'What to look for when assessing South Africa's president, Ramaphosa', The Conversation 14 June. Available at: https://theconversation.com/what-tolook-for-when-assessing-south-africas-president-ramaphosa-97966

Reynolds, A 1999, 'The results', in A Reynolds (ed), Elections 1999 - South Africa, David Philip Publishers, Cape Town.

Sandhotz, W \& Koetzle, W 2000, 'Accounting for Corruption: Economic Structure, Democracy and Trade', International Studies Quarterly, vol. 44, no.1, pp. 31-50. Schlemmer, L 1994, 'South Africa's first open election and the future of its new democracy', in H Giliomee, \& L Schlemmer (eds), The Bold Experiment-South Africa's New Democracy, Southern Book Publishers, Cape Town.

Schulz-Herzenberg, C 2009, 'Trends in Party Support and Voter Behaviour, 19942009, in R Southall \& J Daniel (eds), Zumani! - The 2009 South African Elections, Jacana Media and Conrad Adenauer Foundation, Johannesburg.

Schulz-Herzenberg, C 2012, 'Managing public opinion during the 2009 South African Elections', in HA Thuynsma (ed), Public Opinion and Interest Group Politics - South Africa's Missing Links?, Africa Institute, Pretoria. 
Schulz-Herzenberg, C 2016, 'Shifting Electoral Trends, Participation and Party Support', Journal of Public Administration, vol. 51, no. 3.1, pp. 487-512.

Schulz-Herzenberg, C 2019, 'Trends in voter participation: registration, turnout and the disengaging electorate', in C Schulz-Herzenberg \& R Southall (eds), Election 2019 - Change and stability in South Africa's democracy, Jacana Media, Johannesburg.

South Africa Survey 2017, Institute of Race Relations, Johannesburg.

South Africa Survey 2019, Institute of Race Relations, Johannesburg.

Southall, R 2014, 'The context of the South African election of 2014: Prologue to change? In C Schulz-Herzenberg \& R Southall (eds), Election 2014 - South Africa, Jacana and Konrad Adenauer Stiftung, Johannesburg.

Taylor, R \& Hoeane, T 1999, 'Interpreting the South African Election of June 1999', Politikon, vol. 26, no.2, pp. 133-144.

The Mercury, 2014, 'Grants only for ANC supporters', 9 April. Available at: https:// www.iol.co.za/news/politcs/grants-only-for-anc-supporters-mec-1673290

The Star 2013, 'Ramphele: stop fearing ANC and authority', 26 April. Available at: https://www.iol.co.za/news/politics/ramphele-stop-fearing-anc-andauthority-1506802

Times Live 2019, 'ANC would have dropped to 40\% if Ramaphosa didn't win at Nasrec: Mbalula', 9 May. Available at: https://www.timeslive.co.za/ politics/2019-05-09-anc-would-have-dropped-to-40-if-ramaphosa-didn'twin-at-nasrec-mbalula

Transparency International 2018, ‘Corruption Perceptions Index'. Available at: https://www.transparency.org/cpi2018 